\title{
Incidence of two caterpillar species (Lepidoptera: Crambidae) and injuries caused by them in sweet basil grown in Seropédica County, RJ
}

\author{
Elen de L. Aguiar-Menezes ${ }^{1,2 \pm \equiv}=\mathbb{D}$, Vinicius J. Fernandes ${ }^{2}$, Eurípedes B. Menezes ${ }^{1 \mathbb{D}}$ \\ ${ }^{1}$ Departamento de Entomologia e Fitopatologia, Instituto de Ciências Biológicas e da Saúde, Universidade Federal Rural do Rio de \\ Janeiro (UFRRJ), Seropédica, RJ, Brazil. ²Programa de Pós-Graduação em Fitotecnia, Universidade Federal Rural do Rio de Janeiro \\ (UFRRJ), Seropédica, RJ, Brazil.
}

豐CCorresponding author: elenme@uol.com.br

Edited by: Francisco J. S. Duque

Received: June 02, 2021. Accepted: October 20, 2021. Published: October 29, 2021.

Abstract. Ocimum basilicum L. (Lamiaceae) is one of the most popular herbs in the world, given its aromatic, medicinal and insecticidal properties. Its leaves are rich in essential oils, as well as the plant part with the highest economic value in this species. The aims of the current study are to identify the causative agent of injuries observed in sweet basil plants grown in Seropédica County, RJ (Brazil), as well as to feature both their feeding behavior and injuries caused by them. The herein investigated injuries were caused in sweet basil stems and leaves by caterpillars, which were collected with the leaves and grown in laboratory until they reached the adult stage. Two lepidopteran species belonging to family Crambidae were identified, namely: Hyalorista opalizalis (Guenée, 1854) and Pyrausta phoenicealis (Hübner, 1818); approximately 73\% of adult individuals obtained in laboratory belonged to the first species. Caterpillars belonging to both species have caused similar injuries to $O$. basilicum plants. Injuries were featured by the sectioning of stems whose leaves were bundled with silk threads and formed a shelter, where caterpillars ate the leaf limb in. The current study also recorded $O$. basilicum plants used as hosts by $P$. phoenicealis insects, for the first time.

Keywords: Pyraloid moth, Hyalorista opalizalis, Pyrausta phoenicealis, Ocimum basilicum, Plant-insect interaction.

The genus Ocimum L. (Lamiaceae) comprises a group of aromatic plants of paramount importance worldwide. Among them, one finds sweet basil (Ocimum basilicum L.), which is native to tropical and subtropical regions in Africa, central and southern American and Asia, although it is grown in different countries in commercial and domestic gardens and its leaves are most used by the perfumery and cosmetics industries, aromatherapy products' manufacturing or for medicinal and cooking purposes, a fact that features them as functional food (Shahrajabian et al. 2020).

Sweet basil leaf extracts also have metabolites with insecticidal activity, and it enables using them as insect repellent (Koech 2018; Naveen et al. 2021). Despite its insecticidal activity, sweet basil grown in some regions worldwide can be injured by insects belonging to orders Coleoptera, Hemiptera, Lepidoptera, Orthoptera and Thysanoptera (Olson \& Bidlack 1997; Meek \& Bidlack 2005; Shahrajabian et al. 2020).

Regarding to Lepidoptera, Olson \& Bidlack (1997) and Meek \& Bidlack (2005) cited that defoliating caterpillar belonging to families Arctiidae, Geometridae and Noctuidae can cause severe damage to sweet basil; however, they did not identify the species. However, sweet basil is a host plant for some noctuid species: Autoplusia egena (Guenée, 1852) (Specht et al. 2004), Argyrogramma verruca (Fabricius, 1794), Trichoplusia ni (Hübner, 1803) (Heppner et al. 2007), Rachiplusia nu (Guenée, 1852) (Luz et al. 2014), Spodoptera cosmioides (Walker, 1858) (Pires et al. 2014), Chrysodeixis chalcites (Esper, 1789) (Robinson et al. 2010), Chrysodeixis includens (Walker, [1858]) (Specht et al. 2015) and Spodoptera frugiperda (J. E. Smith, 1797) (Montezano et al. 2018). Other lepidopteran families are also associated with sweet basil: Lycaenidae [e.g., Strymon bazochii (Godart, 1822)] and Pterophoridae [e.g., Stenoptilodes taprobanes (Felder \& Rogenhofer, 1875)] (Robinson et al. 2010).

The aims of the present study were to record the incidence of caterpillars (Lepidoptera) attacking sweet basil ( $O$. basilicum) plants grown in Seropédica County, RJ (Brazil), as well as to feature both their feeding behavior and injuries caused by them.
Sweet basil plants were observed from March $17^{\text {th }}$ to May $17^{\text {th }}$ 2019, in order to investigate the incidence of the following symptoms: sectioned stems presenting their apical part hanging, as well as leaves partly consumed and bundled with silk threads. These plants were grown in home garden beds kept by dwellers in the residential neighborhood of Federal Rural University of Rio de Janeiro (UFRRJ), Seropédica County,

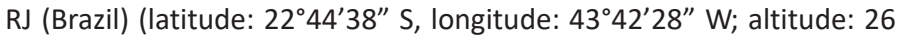
meters). According to the Köppen's classification, the climate in the region is classified as Aw; the rainy season is in Summer, and accounts for mean accumulated rainfall rate of approximately $380 \mathrm{~mm}$; the dry season is in Winter, and accounts for mean accumulated rainfall rate of approximately $88 \mathrm{~mm}$ - mean temperature ranges from $26^{\circ} \mathrm{C}$ to $28^{\circ} \mathrm{C}$ in Summer and from $21^{\circ} \mathrm{C}$ to $24^{\circ} \mathrm{C}$ in Winter.

Thirty-three (33) symptomatic stems with leaves were collected and taken to the laboratory of the Integrated Pest Management Center of the Entomology and Phytopathology Department at UFRRJ to investigate the causative agent of these symptoms. They were placed in transparent $250-\mathrm{mL}$ plastic pots sealed with transparent plastic lid (Fig. 1A), which was perforated with a fine-tipped needle to allow aeration. Each stem was attached to a hole on the pot lid, so that leaves hung inside the pot to simulate their condition in the field. A damp cotton swab was placed at the tip of the stem on the opposite side of the lid to remain leaf turgidity. Pots were remained under controlled environmental conditions (temperature $=25^{\circ} \mathrm{C} \pm 1$ 으, $\mathrm{RH}=70 \%$ and 12-hour photoperiod) and observed every 12 hours - when insect feces fallen to the bottom of the pot (Fig. 1A) were removed; sometimes, caterpillars walking inside some pots were also observed (Fig. 1B).

Caterpillars ready to pupate (approximately $12.0 \pm 0.83 \mathrm{~mm}$ long) choose some point closer to the bottom of the pot (Fig. 1B) and started to weave silk threads to build a pupation chamber, which was overall finished 24 hours later. Leaves were manually separated after feces stopped falling and caterpillars did not leave them to build the pupal chamber, to enable observing the incidence of pupae. Once pupae were found, the stem was removed and the hole in the lid was sealed with 
transparent adhesive tape. Emerged adult individuals were euthanized, mounted on entomological pins and sent to Uiraçu Institute (Camacan, BA, Brazil) for species identification by Dr. Vitor Osmar Becker (moth taxonomist).

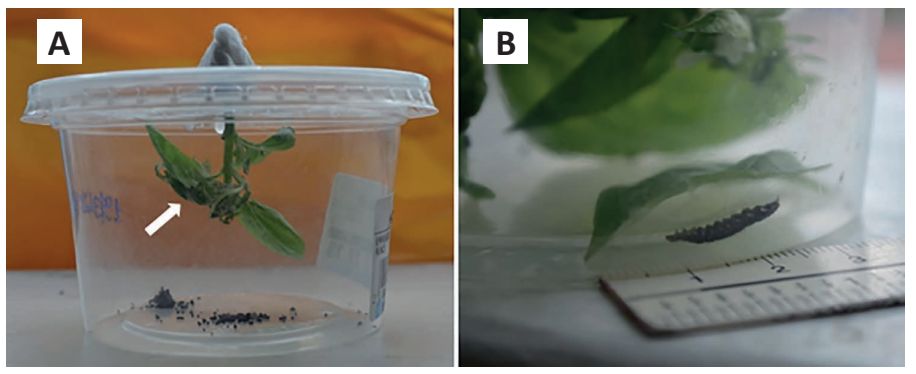

Figure 1. Conditioned stem piece with some Ocimum basilicum leaves bundled with silk threads (white arrow). Stem arrangement in the pot, with emphasis on feces at the bottom of it (A). Caterpillar who left the leaves bundled with silk thread (B).

Two species belonging to subfamily Pyraustinae, family Crambidae (Lepidoptera) were identified, namely: Hyalorista opalizalis (Guenée, 1854) (Figs. 2A, 2B) and Pyrausta phoenicealis (Hübner, 1818) (Figs. $2 C, 2 D)$. There was $100 \%$ of larvae and pupae viability, as well as the emergence of 33 adult individuals (one individual per pot). This outcome has indicated that each shelter was occupied by a single caterpillar. In total, 24 adult individuals belonged to species $H$. opalizalis and 9 adults belonged to species $P$. phoenicealis - caterpillars belonging to both species have caused similar injuries in the investigated plant species.
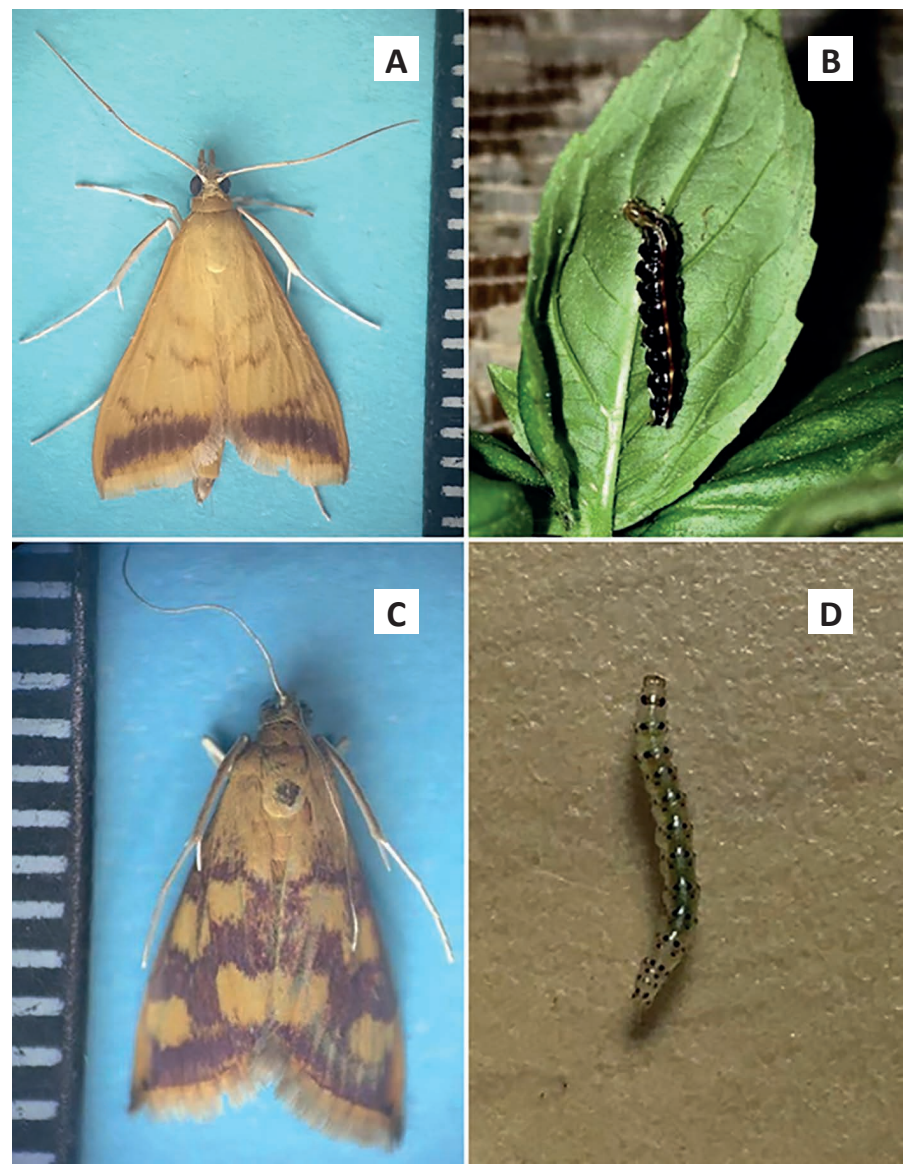

Figure 2. Hyalorista opalizalis: Adult (scale in millimeters) (A), Larva (B); Pyrausto phoenicealis: Adult (scale in millimeters) (C), Larva (D).

Eighteen (18) H. opalizalis larvae pupated outside the shelter, whereas six larvae pupated wrapped by leaves and webs (Fig. 3A). All $P$. phoenicealis larvae pupated out of the shelter. The mean pupal phase time was $11.0 \pm 0.41$ days and $10.5 \pm 0.51$ days for $H$. opalizalis (Fig. $3 \mathrm{~B}$ ) and $P$. phoenicealis, respectively.

Injuries caused by larvae were featured by stem sectioning in the apical part of plants (Fig. 4A). In addition, the upper part of sectioned stems was hanging with its leaves attached to it (Figs. 4A, 4B). These leaves were bundled with silk threads produced by larvae to form a shelter (Fig. 4C). Larvae protected themselves inside the shelter and initially fed on the leaf blade of the adaxial part of plants. Subsequently, the leaf blade was partly or fully consumed, and it exposed the silk threads keeping leaves together and, sometimes, feces on them (Fig. 4C). Leaves withered and finally dried overtime, but they remained attached to the sectioned stems that did not emit new leaves.

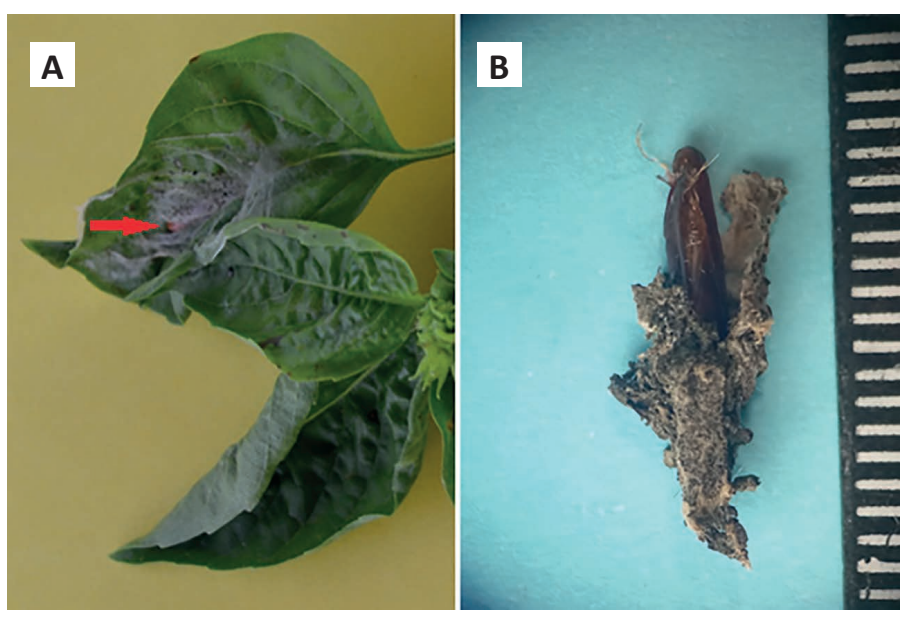

Figure 3. Ocimum basilicum leaf presenting Hyalorista opalizalis pupa (red arrow) amid silk threads (A). Hyalorista opalizalis pupa (scale in millimeters) partly coated with unidentified material mixed with silk threads (B).

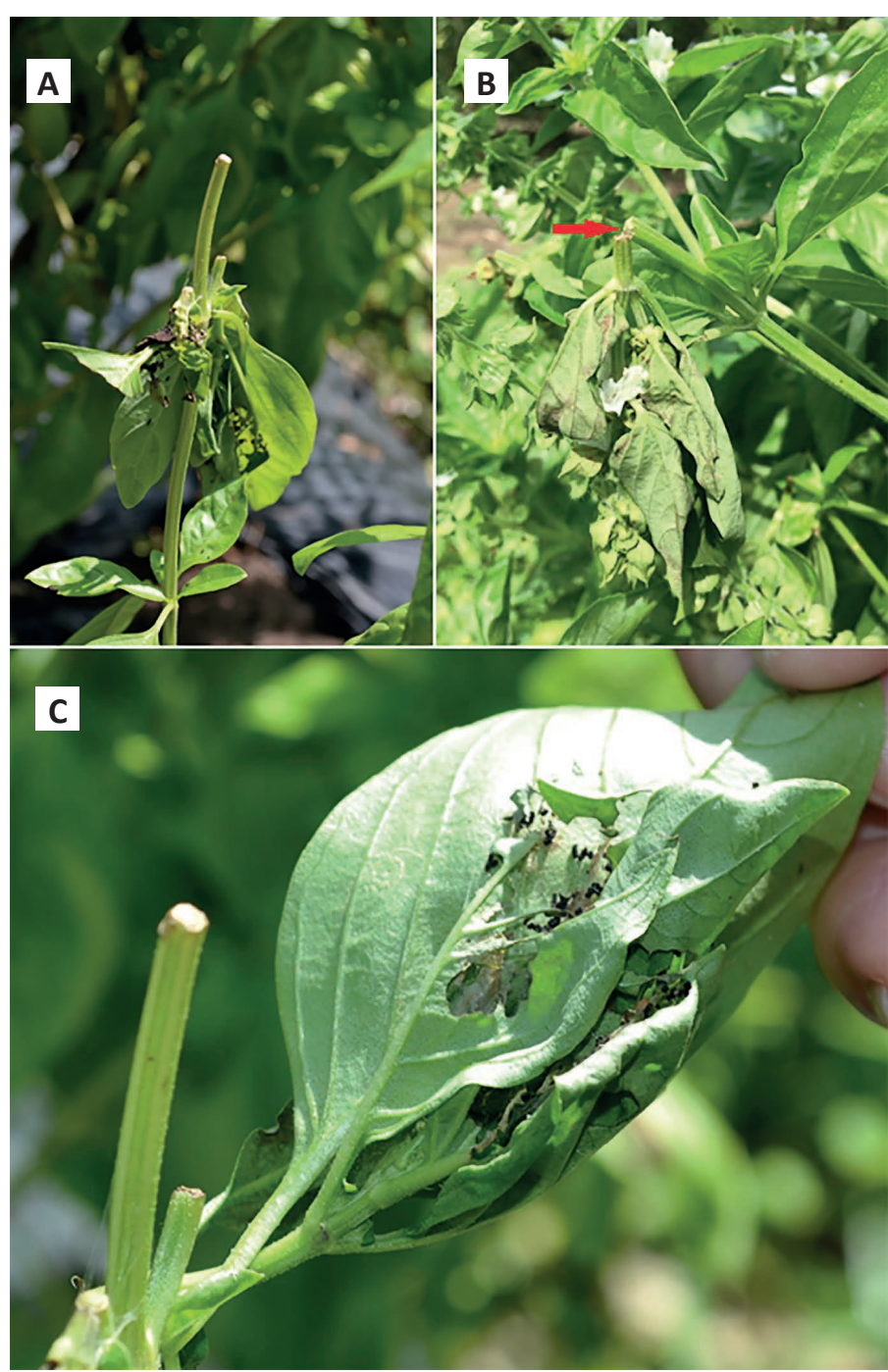

Figure 4. Injuries caused by caterpillar species Hyalorista opalizalis in Ocimum basilicum stems and leaves. Sectioned middle stem and two side stems sectioned further below presenting consumed leaves hanging from them and bundled with silk threads (A). Withered leaves hanging from the sectioned stem (sectioning region shown by red arrow) (B). Leaves with consumed limbs bundled with silk threads and presenting feces (C). 
Pyrausta phoenicealis larvae observed in Seki County, Gifu Province (Japan), were reported to build shelters by wrapping Dicerandra frutescens Shinners (Lamiaceae) leaves and bundling them with silk threads, known as "perilla leaf roller" (Choi et al. 2008). The construction of leafy shelters by caterpillars belonging to family Crambidae was reported in two other species, namely: Syngamia abruptalis Walker, 1859 and Herpetogramma theseusalis (Walker, 1859). In Thailand, S. abruptalis larvae known as 'Ocimum leaf folders' build shelters by wrapping leaves of several species belonging to family Lamiaceae, such as $O$. basilicum; they feed on leaves and pupate inside the shelters (Tigvattnanont 1990). In Maine (USA), H. theseusalis larvae were reported to feed on fern leaves (e.g., Onoclea sensibilis L., Dryopteridaceae) inside shelters built with them, which were rolled up and secured with silk threads (LoPresti \& Morse 2013).

Hyalorista opalizalis was described as Rhodaria opalizalis, based on four adult individuals (two male and two female specimens) collected in Brazil by Achille Guenée in 1854, who did not mention the host plant or the precise collection place location (Guenée 1854; Munroe 1995). Only in the 20th century, Costa Lima (1950) reported that $H$. opalizalis larvae [such as Phlyctaenia (= Pionea) opalizalis (Guenée, 1854)] attack Lamiaceae in Brazil, mainly basil plants (Ocimum sp.) in Rio de Janeiro, as well as marjoram plants in Belo Horizonte, MG. Robinson et al. (2010) have mentioned $O$. basilicum and Origanum majorana (Lamiaceae) as host plants for $\mathrm{H}$. opalizalis (such as $\mathrm{H}$. opalisalis) in Brazil; however, they did not report the information source. These authors also cited Udea rubigalis (Guenée, 1854) associated with $O$. basilicum as its host plant.

Pyrausta phoenicealis is widely distributed worldwide, with emphasis on the Americas, Africa, Australia and Asia (Pastrana 2004; Robinson et al. 2010; Poltavsky et al. 2018). Walker (1859) was the first to record the incidence of this species in Brazil (Rio de Janeiro), although he referred to it by its synonym Rhodaria probalis Walker, 1859. Plant species deriving from eight families were recorded as P. phoenicealis hosts, namely: Asteraceae, Fabaceae, Lamiaceae, Malvaceae, Nyctaginaceae, Poaceae, Rosaceae and Sapindaceae (Pastrana 2004; Robinson et al. 2010; Poltavsky et al. 2018). Nephelium malaiense Griff. (Sapindaceae), Pseudelephantopus spicatus (Juss. ex Aubl.) Rohr (Asteraceae), Stylosanthes erecta P.Beauv. (Fabaceae) and other nine species belonging to family Lamiaceae ( $D$. frutescens, Hyptis brevipes Poit, Hyptis capitata Jacq., Hyptis pectinata (L.) Poit., Mentha arvensis L., Ocimum sanctum L., Perilla frutescens (L.) Britton, Plectranthus rotundifolius (Poir.) Spreng and Rosmarinus officinalis L.) are host of $P$. phoenicealis (Choi et al. 2008; Robinson et al. 2010). In Japan, $P$. phoenicealis is considered a pest to $D$. frutescens, whose buds are damaged by larvae that, in extreme cases, can cut off the main branch of plants (Choi et al. 2008). Syngamia abruptalis was reported as pest to different basil species grown in Thailand (Tigvattnanont 1990).

As $P$. phoenicealis can be categorized as generalist herbivore, its larva can be benefited from mixing foods to improve balanced nutrient intake or reduced exposure to toxic secondary metabolites (Wang et al. 2017) and take advantage over $H$. opalizalis, which seems to be specialized on Lamiaceae, based on the results of the present study combined with aforementioned records of host plants. However, Bernays \& Minkenberg (1997) found that a mixture of different host plants typically does not benefit the performance (survivorship, gain in mass and fecundity) of individual larvae compared to a single food.

In addition, $H$. opalizalis was more abundant than $P$. phoenicealis on $O$. basilicum in the present study. This result corroborates with Braga \& Diniz (2015), who observed that, in general, larvae of specialist folivorous lepidopteran were present at higher densities on a single specific host plants (Roupala montana Aubl.) than generalist ones. However, as pointed out by these authors, many factors (e.g., profile and variation on concentration of secondary metabolites at temporal and spatial scales) may explain the abundance pattern of the specialized vs. generalist insects.

Thus, further studies should be conducted to investigate the potential of $H$. opalizalis and $P$. phoenicealis to become a pest of the sweet basil crop in Brazil, such as those that assess the biological parameters and degrees of specialization or polyphagia of these noctuid species at the population, community, and individual levels (Braga \& Diniz 2015).

To our knowledge, the current study recorded, for the first time, $O$. basilicum plants used as host by $P$. phoenicealis and it has contributed to expand the species' host series. It has also featured, for the first time, the feeding behavior of, and injuries caused by, caterpillar species $H$. opalizalis and $P$. phoenicealis that, after sectioning the stem of $O$. basilicum plants, build shelters with leaves grown in the sectioned stem and eat the leaf blade from within the shelter.

\section{Acknowledgements}

The authors would like to thank Dr. Vitor Osmar Becker (Uiraçu Institute, Camacan County, BA) for identifying the lepidopterans.

\section{Authors' Contributions}

E.L.A.M and E.B.M. designed the study. All authors collected the investigated material in the field, collaborated to insect growth in laboratory environment and collected the corresponding data. E.L.A.M. took the photos, searched for references and wrote the first version of the manuscript. V.J.F mounted the photo boards. E.B.M. and V.J.F revised the manuscript and made improvements to it.

\section{References}

Bernays, E. A.; Minkenberg, O. P. J. M. (1997) Insect herbivores: different reasons for being a generalist. Ecology, 78: 1157-1169. doi: $10.2307 / 2265866$

Braga, L.; Diniz, I. R. (2015) The abundance of specialist and generalist lepidopteran larvae on a single host plant species: does spatial scale matter? Florida Entomologist, 98(3): 954-961. doi: 10.1653/024.098.0323

Choi, Y. S.; Park, D. K.; Yun, Y. U.; Hwang, I. S.; Shin S. M.; Choe, K. R. (2008) Economic injury levels and control thresholds of Pyrausta panopealis Walker (Lepidoptera: Pyralidae) on perilla under greenhouse. Korean Journal Applied Entomology, 47(2): 149-154, 2008. doi: 10.5656/KSAE.2008.47.2.149

Costa Lima, A. M. (1950) Lepidópteros, 2a parte. In: Costa Lima, A. M. (Ed.), Insetos do Brasil, 60 Tomo, pp. 41-42. Rio de Janeiro: Escola Nacional de Agronomia. http://www.ufrrj.br/institutos/ib/ento/ tomo06.pdf. Access on: 6.vi.2021.

Guenée, A. (1854) Deltoïdes et Pyralites. In: Boisduval, J. B. A. D.; Guenée, A. (Eds.), Histoire Naturelle des Insectes. Spécies Général des Lépidoptères. Tome Huitième, p. 171. Paris: Librairie Encyclopédique de Roret. https://ia803109.us.archive.org/35/ items/histoirenaturell08bois/histoirenaturell08bois.pdf. Access on: 6.vi.2021.

Heppner, J. B.; Adair, W. L., Jr.; Baggett, H. D.; Dickel, T. S.; Dow, L. C.; Emmel, T. C.; Habeck, D. H. (2007) Lepidoptera of Florida. Part 1 Introduction and Catalog. Gainesville: Florida Department of Agriculture and Consumer Services, Division of Plant Industry (Arthropods of Florida and Neighboring Land Areas, 17).

Koech, P. (2018) Knockdown effect of sweet basil (Ocimum basilicum) essential oil and a mixed formulation on Aedes aegypti adults. International Journal of Entomology Research, 3(1): 82-85.

LoPresti, E. F.; Morse, D. H. (2013) Costly leaf shelters protect moth pupae from parasitoids. Arthropod-Plant Interactions, 7: 445-453. doi: 10.1007/s11829-013-9261-4

Luz, P. M. C.; Azevedo Filho, W. S.; Specht, A. (2014) Caracterização morfológica dos estágios imaturos de Rachiplusia nu (Guenée, 1852) (Lepidoptera: Noctuidae: Plusiinae) e lista de plantas hospedeiras. Caderno de Pesquisa, série Biologia, 26(3): 65-76. doi: 10.17058/cp.v26i3.5586

Meek, C. R.; Bidlack, J. E. (2005) Arthropod population, phenylalanine ammonia lyase activity, and fresh weight of sweet basil (Ocimum basilicum) as affected by plant age and Bacillus thuringiensis treatment. Proceedings of the Oklahoma Academy of Science, 85: 
9-17.

Montezano, D. G.; Specht, A.; Sosa-Gómez, D. R.; Roque-Specht, V. F.; Sousa-Silva, J. C.; Paula-Moraes, S. V.; Peterson, J. A.; Hunt, T. (2018) Host plants of Spodoptera frugiperda (Lepidoptera: Noctuidae) in the Americas. African Entomology, 26(2): 286-300 (2018). doi: 10.4001/003.026.0286

Munroe, E. G. (1995) Crambidae (Crambinae, Schoenobiinae, Cybalomiinae, Linostinae, Glaphyriinae, Dichogaminae, Scopariinae, Musotiminae, Midilinae, Nymphulinae, Odontiinae, Evergestinae, Pyraustinae). In: Heppner, J. B. (Ed.), Atlas of Neotropical Lepidoptera. Checklist: Part 2. Hyblaeoidea-Pyraloidea - Tortricoidea 3, pp. 34-79. Gainesville: Association for Tropical Lepidoptera \& Scientific Publishers.

Naveen, M.; Jayaraj, J.; Chinniah, C.; Mini, M. L.; Vellaikumar, S.; Shanthi, M. (2021) Insecticidal property of methanolic leaf extract of sweet basil, Ocimum basilicum (L.) against cigarette beetle, Lasioderma serricorne (Fab.) (Coleoptera: Anobiidae). Journal of Entomology and Zoology Studies, 9(1): 259-262. doi: 10.22271/j. ento.2021.v9.i1d.8155

Olson, P. E.; Bidlack, J. E. (1997) Yield and enzyme activity of sweet basil (Ocimum basilicum) subjected to alternative pest control. Journal of Herbs, Spices \& Medicinal Plants, 4(4): 3-16. doi: 10.1300/ J044v04n04_02

Pastrana, J. A. (2004) Los Lepidópteros Argentinos: Sus Plantas Hospedadoras y Otros Sustratos Alimenticios. Buenos Aires: Sociedad Entomológica Argentina.

Pires, E. M.; Manica, C. L. M.; Nogueira, R. M.; Carneiro, J. S.; Rodrigues, W. C.; Soares, M. A. (2014) Coleus barbatus Benth and Ocimum basilicum L. (Lamiaceae), new host plants to Spodoptera cosmioides (Walker) (Lepidoptera: Noctuidae) in Sinop, State of Mato Grosso, Brazil. EntomoBrasilis, 7(1): 62-64. doi: 10.12741/ebrasilis.v7i1.363

Poltavsky, A. N.; Kravchenko, V. D.; Traore, M. M.; Traore, S. F.; Gergely, P.; Witt, T. J.; Sulak, H.; Beck, R. H.-T.; Junnila, A.; Revay, E. E., et al. (2018) The Pyraloidea (Lepidoptera) fauna of the woody savannah belt in Mali, West Africa. Zootaxa, 4457(1): 39-69. doi: 10.11646/ zootaxa.4457.1.2

Popović, Z.; Kostić, M.; Popović, S.; Skorić, S. (2006) Bioactivities of essential oils from basil and sage to Sitophilus oryzae L. Biotechnology \& Biotechnological Equipment, 20(1): 36-40. doi: 10.1080/13102818.2006.10817301

Robinson, G. S.; Ackery, P. R.; Kitching, I. J.; Beccaloni, G. W.; Hernández, L. M. (2010) HOSTS - a Database of the World's Lepidopteran Hostplants. London: Natural History Museum. https://www.nhm. ac.uk/our-science/data/hostplants/. Access on: 6.vi.2021.

Shahrajabian, M. H.; Sun, W.; Cheng, Q. (2020) Chemical components and pharmacological benefits of basil (Ocimum basilicum): a review. International Journal of Food Properties, 23(1): 1961-1970. doi: 10.1080/10942912.2020.1828456

Specht, A.; Paula-Moraes, S. V.; Sosa-Gómez, D. R. (2015) Host plants of Chrysodeixis includens (Walker) (Lepidoptera, Noctuidae, Plusiinae). Revista Brasileira de Entomologia, 59(4): 43-345, 2015. doi: 10.1016/j.rbe.2015.09.002

Specht, A.; Silva, E. J. E.; Link, D. (2004) Noctuídeos (Lepidoptera, Noctuidae) do Museu Entomológico Ceslau Biezanko, Departamento de Fitossanidade, Faculdade de Agronomia "Eliseu Maciel", Universidade Federal de Pelotas, RS. Revista Brasileira de Agrociência, 10(4): 389-409. doi: 10.18539/CAST.V1014.985

Tigvattnanont, S. (1990) Studies on biology of the Ocimum leaf folder, Syngamia abruptalis Walker and its host plants. Khon Kaen Agriculture Journal, 18(6): 316-324.

Walker, F. (1859) List of the Specimens of Lepidopterous Insects in the Collection of the British Museum. Part XIX. Pyralides. London: British Museum (Natural History). https://www.biodiversitylibrary. org/page/38886233\#page/9/mode/1up. Access on: 6.vi.2021.

Wang, Y.; Ma, Y.; Zhou, D-S.; Gao, S.-X.; Zhao, X.-C.; Tang, Q.-B.; Wang, C.Z.; van Loon, J. J. A. (2017) Higher plasticity in feeding preference of a generalist than a specialist: experiments with two closely related Helicoverpa species. Scientific Reports, 7: 17876. doi: 10.1038/ s41598-017-18244-7 